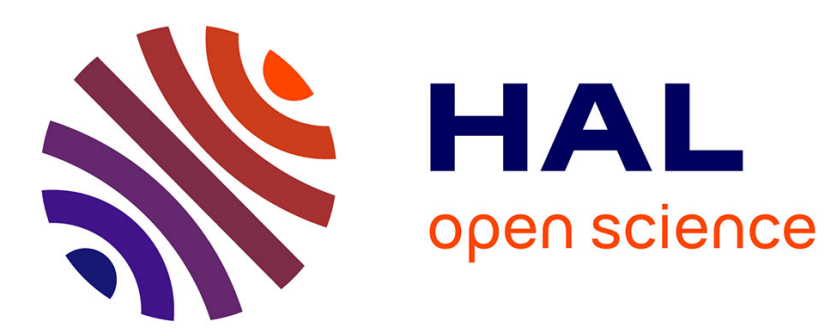

\title{
E-cadherin, guardian of liver physiology
}

Ester Gonzalez-Sanchez, Javier Vaquero, Laura Fouassier, Nicolas Chignard

\section{To cite this version:}

Ester Gonzalez-Sanchez, Javier Vaquero, Laura Fouassier, Nicolas Chignard. E-cadherin, guardian of liver physiology. Clinics and Research in Hepatology and Gastroenterology, 2014, 39 (1), pp.3-6. 10.1016/j.clinre.2014.09.008 . hal-01083673

\section{HAL Id: hal-01083673 https://hal.sorbonne-universite.fr/hal-01083673}

Submitted on 17 Nov 2014

HAL is a multi-disciplinary open access archive for the deposit and dissemination of scientific research documents, whether they are published or not. The documents may come from teaching and research institutions in France or abroad, or from public or private research centers.
L'archive ouverte pluridisciplinaire $\mathbf{H A L}$, est destinée au dépôt et à la diffusion de documents scientifiques de niveau recherche, publiés ou non, émanant des établissements d'enseignement et de recherche français ou étrangers, des laboratoires publics ou privés. 


\section{E-cadherin, guardian of liver physiology}

Gonzalez-Sanchez $\mathrm{E}^{1,2}$, Vaquero $\mathrm{J}^{1,2}$, Fouassier $\mathrm{L}^{1,2}$, Chignard $\mathrm{N}^{1,2}$.

${ }^{1}$ INSERM UMR_S 938, CdR Saint-Antoine, F-75012 Paris, France;

${ }^{2}$ Sorbonne Universités, UPMC Univ Paris 06, F-75012 Paris, France.

\section{Corresponding author:}

Nicolas Chignard, Ph.D.

UPMC, CdR Saint-Antoine, UMR_S 938

Faculté de Médecine Pierre et Marie Curie, site Saint Antoine

27 rue Chaligny

75571 Paris cedex 12, France

E-mail: nicolas.chignard@upmc.fr

Phone: (33) 1-40-01-13-56

Fax: (33) 1-40-01-14-26

Conflict of interest: The authors disclose no conflicts.

Financial support: This work was supported by "Fond CSP Vaincre la Cholangite Sclérosante Primitive" (to Nicolas Chignard), Fondation de France, La Ligue contre le cancer and GEFLUC (to Laura Fouassier). Ester Gonzalez-Sanchez and Javier Vaquero are recipients of postdoctoral fellowships from the Spanish Association for the Study of the Liver (AEEH). 


\section{Summary}

E-cadherin is a cell-cell adhesion molecule involved in epithelial cell behavior, tissue formation and cancer suppression. In the liver, E-cadherin is expressed by hepatocytes and biliary epithelial cells. The precise role of this protein in hepatic pathophysiology remains largely unknown. Recently, loss of E-cadherin in liver epithelial cell types has been shown to lead to periportal fibrosis and inflammation and to promote liver carcinogenesis. 
Cell junctions, such as tight junctions and adherens junctions, organize and protect epithelia. E-cadherin, a major constituent of adherens junctions, establishes cell-cell interactions in epithelia but also participates in several cellular processes such as differentiation and cell signaling [1]. In liver, E-cadherin is expressed by hepatocytes and biliary epithelial cells, however its involvement in hepatic pathophysiology remains largely unknown [2]. Nakagawa et al. have recently shown that absence of E-cadherin leads to inflammatory biliary disease and liver cancer in mice.

Nakagawa et al. produced mice with a liver specific deletion of E-cadherin $\left(C D H 1^{\triangle L}\right)$ by crossing mice carrying floxed $\mathrm{CDHl}\left(\mathrm{CDH}^{\mathrm{F} / F}\right)$ with mice expressing Cre recombinase under the control of the albumin promoter. In the $C D H 1^{\Delta L}$ mice, E-cadherin expression was lost in hepatocytes and biliary epithelial cells of small ducts. Two month after birth, $C D H 1^{\triangle L}$ mice spontaneously developed periportal inflammation. At 8-month of age, periportal fibrosis reminiscent of primary sclerosing cholangitis (PSC) was observed. Morphological analysis of cell junctions by electron microscopy showed no obvious abnormalities in liver epithelial cells. However, injection of fluorescent-labeled bile acid to $C D H 1^{\Delta L}$ mice led to an abnormal canalicular staining and an absence of fluorescence in the bile duct lumen, suggesting that the cholestatic phenotype may be due to a dysfunctional intrahepatic biliary network.

In order to clarify the respective impact of hepatocytes and biliary epithelial cells in the phenotype of the $C D H 1^{\Delta L}$ mice, the authors invalidated specifically E-cadherin in hepatocytes or biliary epithelial cells. E-cadherin expression was invalidated in $73.0 \pm 4.2 \%$ of hepatocytes by injecting an adenovirus expressing Cre-recombinase to $C D H 1^{F / F}$ mice. In these mice, no sign of periportal inflammation nor of portal fibrosis was observed. Conversely, when E-cadherin was deleted in $31.7 \pm 7.2 \%$ of biliary epithelial cells by crossing $C D H 1^{F / F}$ mice with mice carrying tamoxifen inducible Cre-ERT in the K19 locus, periportal inflammation was evidenced in half of the mice. Furthermore, patients with PSC 
displayed abnormal expression of E-cadherin in biliary epithelial cells but not in hepatocytes. Taken together, these results suggest that abnormal expression of E-cadherin in biliary epithelial cells may lead to the development of a PSC-like phenotype.

In order to better define the molecular mechanisms leading to a PSC-like phenotype, the authors performed a cDNA microarray analysis of the $C D H 1^{\Delta L}$ mouse liver. Expression of progenitor cell markers such as Sox9, CD44 and Epcam was increased in $C D H 1^{\Delta L}$ mice compared to wild type mice. These progenitor cell markers were mainly expressed in primitive duct cells involved in the ductular reaction. Immuno-histological analysis of Ki67 expression indicated that in $C D H 1^{\Delta L}$ mice primitive duct cells actively proliferate, while hepatocytes do not. In $C D H 1^{\Delta L}$ mice, liver expression of proinflammatory mediators was also increased, while the number of infiltrated macrophages was higher. Interestingly, proinflammatory cytokines have been implicated in hepatic progenitor cell induction. Accordingly, macrophage depletion induced by liposomal clodronate reduced ductular reaction in $C D H 1^{\Delta L}$ mice.

At 11-month of age, liver tumors were evidenced in $16.7 \%$ of $C D H 1^{\Delta L}$ mice, suggesting that the absence of E-cadherin can directly lead to the development of tumors. To investigate the mechanisms leading to liver cancer in these mice, the authors generated $C D H 1^{\triangle L}$ mice expressing active hepatic $\mathrm{Kras}\left(\mathrm{Kras}_{\mathrm{CDH}} \mathrm{CL}^{\Delta L}\right.$ mice). E-cadherin loss significantly accelerated tumorigenesis induced by Ras activation in mice, as shown by tumor number and size evaluation. All Kras/CDH1 $1^{\Delta L}$ mice developed hepatocellular carcinoma (HCC) tumors. Cholangiocellular carcinoma (CCC) and mixed type HCC/CCC tumors were also seen in 10\% and $40 \%$ of the mice, respectively. The enhanced carcinogenesis observed in $\mathrm{Kras} / \mathrm{CDH} 1^{\Delta L}$ mice was ascribed to an increase in the phosphorylation of ERK and of the epithelial growth factor receptor, EGFR. Because EGFR is a potent inducer of epithelial-mesenchymal transition (EMT) in liver tumor cells, the authors next evaluated EMT features in the hepatic 
tumors of $\mathrm{Kras} / \mathrm{CDH}^{\Delta L}$ mice. Loss of E-cadherin was accompanied by an increased expression of both mesenchymal (i.e. vimentin) and stem cell markers (i.e. CD44 and Sox9) in these tumors and in human HCC derived cell lines. Furthermore, small nodules near tumors expressed the same types of markers suggesting intrahepatic metastatic processes. Thus, these results suggest that loss of E-cadherin has a causal role in EMT and the invasive phenotype of liver cancer.

In summary, Nakagawa et al. show that loss of E-cadherin in biliary epithelial cells leads to inflammation and subsequent periductal fibrosis reminiscent of PSC. Furthermore, the work of Nakagawa et al. indicates that loss of E-cadherin in hepatocytes and biliary epithelial cells accelerates liver carcinogenesis and favors tumor invasiveness.

The establishment of cell junctions between epithelial cells is crucial for the normal organization of liver functions, such as bile secretion [1]. Consistently, alterations in tight junctions have been related to cholestatic liver diseases, such as the neonatal ichthyosis and sclerosing cholangitis (NISCH) syndrome [3], primary biliary cirrhosis (PBC) and PSC [4]. Furthermore, expression of E-cadherin may also be altered in the liver of patients with arthrogryposis, renal dysfunction and cholestasis (ARC) [5], a syndrome for which liver features include paucity of bile ducts, cholestasis and mild inflammation [6]. We have recently shown that, during experimental bile duct obstruction, adherens junctions were altered by the expression of a truncated form of E-cadherin. Furthermore, our data indicate that liver injury was exacerbated when the truncated E-cadherin expression was increased [7]. Here, Nakagawa et al. show that the absence of hepatic E-cadherin leads to a cholestatic phenotype evocative of PSC. Adherens junctions in hepatocytes and biliary epithelial cells were not altered in 2-month old $C D H 1^{\Delta L}$ mice, as shown by electronic microscopy analysis. However, bile acid secretion into bile ducts was impaired in these mice. The latter observation could reflect adaptive mechanisms able to compensate for adherens junctions organization but 
not for E-cadherin signaling functions. In this context, the analysis of the expression and localization of transporters in hepatocytes and biliary epithelial cells would be valuable. In the adult mouse liver, E-cadherin expression is restricted to peri-portal hepatocytes, while in perivenous hepatocytes $\mathrm{N}$-cadherin is expressed [8]. Because E-cadherin and $\mathrm{N}$-cadherin zonation takes place after birth [8], N-cadherin could compensate for the hepatic absence of Ecadherin. Furthermore, adherens junctions morphological analysis was performed in 2-month old animals while the cholestatic phenotype was evident at 8-month of age (ALP levels, histology). Thus, altered adherens junctions morphology may appear later in the $C D H 1^{\Delta L}$ mice as we have previously shown that E-cadherin alterations were increased when cholestasis was established in $V d r^{-/-}$mice [7].

$C D H 1^{\Delta L}$ mice show signs of ductular reaction and portal inflammation at 2-month of age. The latter observations may account for the inflammatory and proliferative effects of bile acids on liver cells $[9,10]$. However, eight weeks after E-cadherin expression was specifically suppressed in hepatocytes, no sign of portal inflammation or ductular reaction could be evidenced. In contrast, specific invalidation of E-cadherin in biliary epithelial cells was associated with portal inflammation and ductular reaction. Consistently, mice invalidated for hepatic E-cadherin that maintain E-cadherin expression in non-hepatocyte cells do not show ductular proliferation and portal fibrosis [11]. Thus, accumulation of bile acids in the portal space may be the first trigger inducing inflammation and proliferation of biliary epithelial cells. Proliferating biliary epithelial cells devoid of E-cadherin may be unable to assemble new adherens junctions, as previously described in other epithelial cells [12], leading to the formation of leaky bile ducts. Leaky bile ducts would then favor the release of toxic compounds, such as bile acids and endotoxins, from bile. The latter would lead to the recruitment of macrophages that are major inducers of the ductular reaction through the 
release of inflammatory cytokines (i.e. IL-6). Thus, a vicious circle of inflammation and proliferation is set by the absence of E-cadherin in the portal space.

The ductular reaction observed in $C D H I^{\Delta L}$ mice was associated with an increased expression of K19. The over-expression of K19 is indicative of biliary epithelial cell proliferation, but also of the presence of bi-potential hepatic progenitor cells. Bi-potential hepatic progenitor cells have the ability to differentiate either into hepatocytes or biliary epithelial cells [13] and may be involved in the development of HCC and CCC [14]. Consistently, a few $C D H 1^{\Delta L}$ mice spontaneously developed liver tumors. Furthermore, all $C D H 1^{\Delta L}$ mice in which hepatic Ras signaling is active (Kras/CDH1 $1^{\Delta L}$ mice) developed tumors (i.e. HCC, CCC or HCC/CCC tumors). The fact that the number of tumor rises when carcinogenesis is primed in mice deficient for liver E-cadherin, indicates that E-cadherin is mainly involved in the progression of the primary tumors. Consistently DEN-induced HCC tumor growth is accelerated in liver of E-cadherin deficient mice [11].

Analysis of cell signaling indicates that EGFR activation is central in liver tumorigenesis of Kras $/ C D H 1^{\Delta L}$ mice. E-cadherin and EGFR have well documented interactions in the context of cancer [15-17]. In CCC cells, E-cadherin colocalizes with EGFR [18], while E-cadherin displays inhibitory activities towards EGFR [17]. Thus, absence of E-cadherin may favor cell proliferation, migration and invasion by activating EGFR pathways [17, 19, 20]. Furthermore, we have recently shown that CCC cells produce TGF- $\beta 1$ that in turn activates myofibroblasts from the tumor stroma. These myofibroblasts will produce HB-EGF that in a paracrine loop activates EGFR on CCC cells [21]. Thus, the absence of E-cadherin in biliary epithelial cells should activate the EGFR pathway leading to TGF- $\beta 1$ production. TGF- $\beta 1$ will increase HBEGF production by mesenchymal cells of the portal space that will in turn favor biliary epithelial cell proliferation and EMT through EGFR signaling [22-24]. Interestingly, the observation of CCC tumors in mice lacking hepatic E-cadherin recapitulates the 
pathophysiological continuum of PSC, a well-known pathology associated with CCC development [25].

In conclusion, Nakagawa et al. show that dysregulation of E-cadherin expression in epithelial liver cells is sufficient to induce portal fibrosis and liver cancer. Even though it is still unclear how the specific absence of E-cadherin leads to a PSC-like phenotype, the demonstration that PSC may arise solely from biliary epithelial cells is a disruptive concept. Finally, the authors also demonstrate that the absence of E-cadherin in liver epithelial cells favors carcinogenesis and intrahepatic metastasis. The origin of these tumors needs however further clarifications. Taken together, the observations of Nakagawa et al. suggest that stabilization of adherens junctions in epithelial liver cells may prevent inflammatory biliary disease and liver cancer. 


\section{References}

1. Vinken M, Papeleu P, Snykers S, De Rop E, Henkens T, Chipman JK, Rogiers V, et al. Involvement of cell junctions in hepatocyte culture functionality. Crit Rev Toxicol 2006;36:299-318.

2. Ihara A, Koizumi H, Hashizume R, Uchikoshi T. Expression of epithelial cadherin and alpha- and beta-catenins in nontumoral livers and hepatocellular carcinomas. Hepatology 1996;23:1441-1447.

3. Hadj-Rabia S, Baala L, Vabres P, Hamel-Teillac D, Jacquemin E, Fabre M, Lyonnet S, et al. Claudin-1 gene mutations in neonatal sclerosing cholangitis associated with ichthyosis: a tight junction disease. Gastroenterology 2004;127:1386-1390.

4. Sakisaka S, Kawaguchi T, Taniguchi E, Hanada S, Sasatomi K, Koga H, Harada M, et al. Alterations in tight junctions differ between primary biliary cirrhosis and primary sclerosing cholangitis. Hepatology 2001;33:1460-1468.

5. Cullinane AR, Straatman-Iwanowska A, Zaucker A, Wakabayashi Y, Bruce CK, Luo G, Rahman F, et al. Mutations in VIPAR cause an arthrogryposis, renal dysfunction and cholestasis syndrome phenotype with defects in epithelial polarization. Nat Genet 2010;42:303-312.

6. Horslen SP, Quarrell OW, Tanner MS. Liver histology in the arthrogryposis multiplex congenita, renal dysfunction, and cholestasis (ARC) syndrome: report of three new cases and review. J Med Genet 1994;31:62-64.

7. Firrincieli D, Zuniga S, Rey C, Wendum D, Lasnier E, Rainteau D, Braescu T, et al. Vitamin D nuclear receptor deficiency promotes cholestatic liver injury by disruption of biliary epithelial cell junctions in mice. Hepatology 2013;58:1401-1412.

8. Doi Y, Tamura S, Nammo T, Fukui K, Kiso S, Nagafuchi A. Development of complementary expression patterns of $\mathrm{E}$ - and $\mathrm{N}$-cadherin in the mouse liver. Hepatol Res 2007;37:230-237.

9. Allen K, Jaeschke H, Copple BL. Bile acids induce inflammatory genes in hepatocytes: a novel mechanism of inflammation during obstructive cholestasis. Am J Pathol 2011;178:175186.

10. Huang W, Ma K, Zhang J, Qatanani M, Cuvillier J, Liu J, Dong B, et al. Nuclear receptordependent bile acid signaling is required for normal liver regeneration. Science 2006;312:233236. 
11. Schneider MR, Hiltwein F, Grill J, Blum H, Krebs S, Klanner A, Bauersachs S, et al. Evidence for a role of E-cadherin in suppressing liver carcinogenesis in mice and men. Carcinogenesis 2014;35:1855-1862.

12. Capaldo CT, Macara IG. Depletion of E-cadherin disrupts establishment but not maintenance of cell junctions in Madin-Darby canine kidney epithelial cells. Mol Biol Cell 2007;18:189-200.

13. Roskams T, De Vos R, Van Eyken P, Myazaki H, Van Damme B, Desmet V. Hepatic OV-6 expression in human liver disease and rat experiments: evidence for hepatic progenitor cells in man. J Hepatol 1998;29:455-463.

14. Roskams T. Liver stem cells and their implication in hepatocellular and cholangiocarcinoma. Oncogene 2006;25:3818-3822.

15. Claperon A, Mergey M, Fouassier L. Roles of the scaffolding proteins NHERF in liver biology. Clin Res Hepatol Gastroenterol 2011;35:176-181.

16. Curto M, Cole BK, Lallemand D, Liu CH, McClatchey AI. Contact-dependent inhibition of EGFR signaling by Nf2/Merlin. J Cell Biol 2007;177:893-903.

17. Qian X, Karpova T, Sheppard AM, McNally J, Lowy DR. E-cadherin-mediated adhesion inhibits ligand-dependent activation of diverse receptor tyrosine kinases. EMBO $J$ 2004;23:1739-1748.

18. Claperon A, Guedj N, Mergey M, Vignjevic D, Desbois-Mouthon C, Boissan M, Saubamea B, et al. Loss of EBP50 stimulates EGFR activity to induce EMT phenotypic features in biliary cancer cells. Oncogene 2012;31:1376-1388.

19. Claperon A, Mergey M, Nguyen Ho-Bouldoires TH, Vignjevic D, Wendum D, Chretien $\mathrm{Y}$, Merabtene F, et al. EGF/EGFR axis contributes to the progression of cholangiocarcinoma through the induction of an epithelial-mesenchymal transition. J Hepatol 2014;61:325-332.

20. Liu ZC, Chen XH, Song HX, Wang HS, Zhang G, Wang H, Chen DY, et al. Snail regulated by PKC/GSK-3beta pathway is crucial for EGF-induced epithelial-mesenchymal transition (EMT) of cancer cells. Cell Tissue Res 2014.

21. Claperon A, Mergey M, Aoudjehane L, Ho-Bouldoires TH, Wendum D, Prignon A, Merabtene F, et al. Hepatic myofibroblasts promote the progression of human cholangiocarcinoma through activation of epidermal growth factor receptor. Hepatology 2013;58:2001-2011.

22. Drucker C, Parzefall W, Teufelhofer O, Grusch M, Ellinger A, Schulte-Hermann R, Grasl-Kraupp B. Non-parenchymal liver cells support the growth advantage in the first stages of hepatocarcinogenesis. Carcinogenesis 2006;27:152-161. 
23. Ito Y, Takeda T, Higashiyama S, Sakon M, Wakasa KI, Tsujimoto M, Monden M, et al. Expression of heparin binding epidermal growth factor-like growth factor in hepatocellular carcinoma: an immunohistochemical study. Oncol Rep 2001;8:903-907.

24. Sagmeister S, Drucker C, Losert A, Grusch M, Daryabeigi A, Parzefall W, Rohr-Udilova $\mathrm{N}$, et al. HB-EGF is a paracrine growth stimulator for early tumor prestages in inflammationassociated hepatocarcinogenesis. J Hepatol 2008;49:955-964.

25. Razumilava N, Gores GJ. Cholangiocarcinoma. Lancet 2014;383:2168-2179. 